\title{
EVALUASI EFEKTIFITAS INISIASI MENYUSU DINI (IMD) TERHADAP KELANCARAN ASI PADA IBU NIFAS DI RUANG DAHLIA RUMAH SAKIT TK II UDAYANA DENPASAR
}

\author{
Evaluation Of The Effectiveness Of Early Breastfeeding Initiation (IMD) Towards \\ Breast Milk In Public Mothers In Dahlia Room, Tk II Udayana Hospital, Denpasar
}

\author{
Ni Wayan Purwaningsih ${ }^{1}$, Luh Putu Widiastini ${ }^{2}$ \\ ${ }^{1}$ Jurusan Kebidanan, Stikes Bina Usada Bali, Indonesia \\ ${ }^{2}$ Jurusan Kebidanan, Stikes Bina Usada Bali, Indonesia \\ Korespondensi: Luh Putu Widiastini dan enick.dilaga@gmail.com
}

\begin{abstract}
ABSTRAK
Latar Belakang: Inisiasi Menyusu Dini (early initiation) dini adalah mulai menyusu sendiri segera setelah lahir. sehingga pengeluaran ASI menjadi lancar maka kebutuhan bayi akan ASI akan terpenuhi. Tujuan Penelitian: Tujuan penelitian untuk mengevaluasi efektivitas inisiasi menyusu dini terhadap kelancaran ASI. Metedologi: Metode penelitian ini adalah kualitatif dengan jenis penelitian evaluasi sumatif, partisipan dalam penelitian ini adalah ibu bersalin di Rumah sakit Tk II Udayana Denpasar yang telah melakukan Inisiasi menyusu Dini. Pengambilan data dilakukan dengan cara wawancara mendalam dan observasi kepada partaisipan, keluarga dan tenaga kesehatan di ruang Dahlia Rumah Sakit TK II udayana Denpasar, kemudian dilakukan triangulasi. Hasil: Dari hasil penelitian di dapatkan karakteristik payudara tegang, kencang serta ditandai dengan payudara partisipan yang membesar dan ASI merembes. Hal tersebut menunjukan bahwa payudara partisipan produksi ASInya banyak. Serta bayi partisipan tidur tenang/pulas 3-4 jam, mengganti popok karena buang air kecil/besar 8-10 kali/hari, menyusu 10-12 kali/hari dengan lama 15 menit ini menunjukkan bahwa pengeluaran ASI partisipan lancar. Kesimpulan: Dalam penelitian ini dapat disimpulkan bahwa Rumah Sakit TK II Udayana Denpasar belum melaksanakan program IMD dan akan melakasanakan program IMD kemudian dikembangkan melihat begitu banyak manfaat yang diperoleh bagi ibu dan bayinya.
\end{abstract}

Kata Kunci: Evaluasi; IMD; kelancaran ASI.

\section{ABSTRACT}

Background: Early breastfeeding initation is the process of starting breastfeeding immediately after delivery process therefore it can make breast milik production smoothly and infant's demand will be met. Objectives: This study aimed at evaluating the affectiveness of early breastfeeding towards smooth breast milik production. Methodology: This study used qualitative method withh summative evaluation. The participants in this study were postpartum mother's in Udayana Hospital II Denpasar who had applied early breastfeeding initiation. The data was collected through depth interview and observation to the participant, family and health staffs in Dahlia ward in Udayana Hospital II Denpasar, and then triangulation was conducted. Result: From the result of this study could be obtained the characteristic of the breast was tense, rapid, getting bigger and seeping breast milk. This condition showed that participant's breast had much quantity of breast milk. The infants could 
sleep well 3-4 hours, changed diaper diaper due to high quantity of urinate was 8-10 times/day, breastfeeding 10-12 times/day for 15 minutes. It showed that participant's breast milk production was smooth. Conclusion: It could be concluded that Udayana Hospital II Denpasar had not implemented early breastfeeding initiation yet, and it will be further implementation because of the benefit points for mother and baby.

Keywords: Evaluation; early initiation of breastfeeding; smooth mother's milk.

\section{PENDAHULUAN}

Setiap ibu menyusu menghasilkan air susu yang disebut Air Susu Ibu (ASI) sebagai makanan alami yang disediakan untuk bayi. ASI mengandung bermacammacam enzim yang menguntungkan bagi bayi antara lain enzim lipase yang berfungsi mencerna lemak sehingga ASI lebih cepat dan mudah dicerna oleh bayi. Enzim-enzim yang terkandung di dalam ASI juga sangat berperan dalam melindungi dan menghindarkan bayi dari berbagai penyakit (Sarwono, 2008).

Menurut Survey Demografi Kesehatan Indonesia 4 tahun terakhir di Indonesia hanya $4 \%$ bayi yang mendapatkan ASI dalam satu jam kelahirannya. Menurut dokter di RS Carolus dengan memisahkan ibu dengan bayinya ternyata hormon stress pada bayi akan meningkat 50\%, sehingga kekebalan dan daya tahan tubuh bayi drop sampai $25 \%$. Bayi dalam kondisi prima bila dekat dengan ibunya dan ibu dapat melakukan proteksi terhadap bayinya jika diperlukan. Dokter juga mengatakan $95 \%$ bayi menangis bukan karena kelaparan, tapi karena dipisahkan dari ibunya. Bayi baru lahir dibekali dari rahim ibunya untuk bertahan selama 2-3 hari tanpa makanan sehingga program "Inisiasi Menyusu Dini" dapat menyelamatkan sekurangnya 30.000 bayi di Indonesia yang meninggal dalam bulan pertama kelahiran (Susilawati, 2010).

Inisiasi Menyusu Dini (IMD) yaitu memberikan ASI kepada bayi baru lahir, bayi tidak boleh dibersihkan terlebih dahulu dan tidak dipisahkan dari ibu.
Pada Inisiasi Menyusu Dini ibu segera mendekap dan membiarkan bayi menyusu dalam 1 jam pertama kelahirannya (Roesli, 2010). Inisiasi Menyusu Dini dapat memberikan kesempatan pada bayi untuk mulai menyusu segera setelah dilahirkan.

Dari studi pendahuluan yang dilakukan peneliti pada tanggal $16 \mathrm{Mei}$ 2016 di Ruang Dahlia Rumah Sakit Tk II Udayana Denpasar, diperoleh informasi tentang jumlah ibu bersalinan. Hasil wawancara dan dokumentasi didapat data bahwa pada bulan Februari 2016 terdapat $38 \mathrm{ibu}$ bersalin, bulan Maret 2016 terdapat $42 \mathrm{ibu}$ bersalin, bulan April 2016 terdapat 34 ibu bersalin, dan pada bulan Mei 2016 terdapat 27 ibu bersalin. Hasil wawancara pada tanggal 16 Mei 2016 dengan 7 ibu bersalin didapatkan data subjektif bahwa saat bersalin bayinya diberi kesempatan untuk merangkak mencari payudara untuk menyusu serta menghisap puting susu secara mandiri, dan setelah dilakukan Inisiasi Menyusu Dini (IMD), ASI menjadi lancar dan ketika semakin sering bayi menyusu produksi ASI semakin meningkat dan dapat keluar secara lancar. Masih banyak ditemukan kurangnya penerapan Inisiasi Menyusu Dini (IMD) pada ibu bersalin di Ruang Dahlia RS Tk II Udayana Denpasar . Berdasarkan latar belakang di atas bahwa Inisiasi Menyusu Dini (IMD) mempengaruhi kelancaran ASI.

\section{TUJUAN PENELITIAN}

$\begin{array}{ccr}\text { Evaluasi } & \text { Efektifitas } & \text { Inisiasi } \\ \text { Menyusu Dini } & \text { (IMD) } & \text { terhadap }\end{array}$


Kelancaran ASI pada Ibu Nifas di Ruang Dahlia Rumah Sakit Tk II Udayana Denpasar

\section{METODE PENELITIAN}

Desain penelitian yang digunakan dalam penelitian ini adalah penelitian kualitatif, dengan menggunakan pendekatan evaluasi sumatif karena tujuannya

Peneliti bermaksud memahami bagaimana efektifitas dari suatu program Inisiasi Menyusu Dini (IMD) terhadap kelancaran ASI. Kemudian mengevaluasi program ini apakah program tersebut akan tetap dilanjutkan, dikembangkan atau bahkan dihentikan

\section{HASIL PENELITIAN}

Berikut adalah hasil wawancara dan observasi yang dilakukan bersamaan dengan tujuan mengevaluasi efektifitas Inisiasi Menyusu Dini terhadap kelancaran ASI di Rumah Sakit TK II Udayana Denpasar. Data yang diperoleh dari wawancara di cross check dengan data yang diperoleh melalui observasi dengan indikator kelancaran ASI.

Hasil penelitian seperti berikut :

1. Apakah ibu sudah mengetahui manfaat ASI? Jika iya dapatkah ibu sebutkan?

Sebelas partisipan $(100 \%)$ dalam wawancara mengatakan pernah mendengar IMD (Inisiasi Menyusu Dini) dan melakuan program IMD (Inisiasi Menyusu Dini) setelah lahir.

$Y a$ tau $m b$, duh banyak banget manfaatnya... vitamin, sumber makanan untuk si dedek (partisipan 1,2,4,5,6,8,10) (partisipan terlihat serius)

Taulah ASI pokoknya paling bagus untuk bayi... manfaatnya banyak sekali kekebalan, asupan nutrisinya banyak lagi (partisipan 3,7,9,11) (partisipan terlihat mengkerutkan kening)
Hasil triangulasi yang diperoleh peneliti melalui obsevasi adalah bahwa dari 11 partisipan semua telah mengetahui manfaat ASI dan semua partisipan setuju bahwa ASI merupakan makanan terbaik untuk bayi. Dari hasil observasi partisipan telah melakukan IMD setelah melahirkan, yang di tandai bayi partisipan mampu menyusu dengan baik.

2. Apakah ibu pernah mendengar atau ibu sudah mengetahui apa itu IMD (Inisiasi Menyusu Dini)? Kapan pelaksanaan IMD (Inisiasi Menyusu Dini) dilakukan setelah proses persalinan?

Sebelas partisipan (100\%) dalam wawancara mengatakan pernah mengetahui IMD (Inisiasi Menyusu Dini) dan melakuan program IMD (Inisiasi Menyusu Dini) setelah lahir.

Yaaaa mb nyusu langsung setelah lahir yaaa,,,,,(partisipan 1,3,,9)(partisipan terlihat menggangkat alis dan lama menjawab)

Eeee pernah dikasi tau waktu control bulanan mb sama dokternya, bis lahiran bayi saya tak susui mb,,,,,(partisipan 2,5,6,8) (partisipan menjawab sambil tertawa)

Tau mb saya menyusu setelah lahir ya mb? Tak lakuin mb (partisipan 4)(partisipan terlihat ekpresi datar)

Oyaaa tau saya mb heeee.... Saya juga sering dengar kegunaannya saya juga cari di internet $m b,,,$, (partisipan 10) (partisipan menjawab sambil tertawa)

Pernah dengar mb,,, saya capek bis lahiran tapi tetep tak susui ....(partisipan 7,11) (partisipan raut muka kelelahan)

Hasil triangulasi yang diperoleh peneliti melalui obsevasi adalah bahwa dari 11 partisipan semua telah mengetahui IMD (Inisiasi Menyusu Dini). Dari hasil observasi partisipan telah melakukan Inisiasi Menyusu Dini 
setelah melahirkan, yang di tandai bayi partisipan mampu menyusu dengan baik.

3. Apakah ibu mengetahui manfaat IMD (Inisiasi Menyusu Dini)

Sebelas partisipan $(100 \%)$ dalam wawancara mengatakan pernah mengetahui manfaat IMD (Inisiasi Menyusu Dini) dan melakuan program IMD (Inisiasi Menyusu Dini) setelah lahir.

Yaaaa mb nyusu langsung setelah lahir yaaa,,,,,(partisipan 1,3,,9) (partisipan terlihat bersemangat)

Eeee pernah dikasi tau waktu kontrol bulanan mb sama dokternya bis lahiran bayi saya tak susui mb,,,,,(partisipan $2,5,6,8)$ (partisipan terlihat malu malu)

Tau mb saya menyusu setelah lahir ya $m b$ ? Tak lakuin mb (partisipan 4)(partisipan terlihat serius)

Oyaaa tau saya mb heeee.... Saya juga sering dengar kegunaannya saya juga cari di internet mb,,,,(patisipan 10)(partisipan terlihat santai)

Pernah dengar mb tapi saya capek bis

\section{7,11)(partisipan terihat kelelahan)}

Hasil triangulasi yang diperoleh peneliti melalui obsevasi adalah bahwa dari 11 partisipan semua telah mengetahui IMD (Inisiasi Menyusu Dini). Dari hasil observasi partisipan telah melakukan Inisiasi Menyusu Dini setelah melahirkan, yang di tandai bayi partisipan mampu menyusu dengan baik.

4. Apakah setelah melahirkan ibu terlalu lelah untuk menyusui? Apakah yang memotivasi ibu untuk melakukan IMD (Inisiasi Menyusu Dini)?

Semua partisipan $100 \quad \%$ mengatakan lelah saat melahirkan tapi masih mampu menyusui bayinya.

Waktu bayi sudah diluar .... duhh leganya kayak plong baget,,, capek mb, tp melihat anak rasanya gimana gitu...senang baget waktu menyusui (partisipan1,4)(partisipan terlihat masih lemah)

Duh leganya loe dah lahir,,, capek waktu lahir hilang mb,,,lucu (partisipan 2,5,6)(partisipan terlihat senyum senyum)

Ringan rasanya, dari sakit nya gak tau mana yang sakit setelah lahir hilang, lemes bis lahir, tapi saya langsung dkasi dan saya susui (partisipan 3,10)(partisipan terlihat mengelus perut)

Bebas rasanya ,,, capeknya hilang sudah, dia nagis trus tak susui (partisipan 7)(partisipan terlihat mengelus kening anak sambil disusui)

Lega sekali... lemes baget, yaa tak susui (partisipan 8,9,11)(partisipan terlihat lemah)

Hasil triangulasi yang diperoleh peneliti melalui obsevasi adalah bahwa semua partisipan mengatakan sangat lega saat melahirkan, meskipun lelah tapi tetap semangat menyusui anaknya. Sesuai hasil observasi semua bayi mampu menyusui bayinya. Pada observasi 24 jam pertama semua bayi dan ibu mampu menyusu. Dan pada 72 jam pertama bayi mampu nyusu dan menyusu yang benar.

5. Apakah ASI ibu sudah mulai keluar? Banyak atau sedikit? Berapa lama ibu melakukan IMD (Inisiasi Menyusu Dini)?

Delapan partisipan $(70 \%)$ dalam wawancara mengatakan bahwa sebelum disusukan payudara patisipan terasa kencang/tegang seperti kutipan di bawah ini :

"Ya sekarang kencang mb....sampek netes bajunya basah hehehee berapa lama ya lupa mb.. ya kira ada segitu (30 menit)"'(partisipan 1,7,9,11) (partisipan terlihat tertawa malu)

"bengkak, kayak ya membesar aj trus merembes loe gk disusui...kira kira ada setengah jamanlah"(partisipan 2) (partisipan sambil memegang payudaranya) 
"ya biasa kalau menyusui itu payudaranya emang kayak gini ... ya itu kencang hehehe (tertawa)...." ASI nya keluar sendiri loe lgi penuh yaaa lumayan lama sie gak tau tepatnya" (partsipan 3) (partisipan terlihat tertawa)

"Ya terasa ASInya penuh aja trus keluar sendiri nanti .... berpa ya duh gak ngitung, tapi lumayan lah".(partisipan 4) (partisipan terlihat mengerutkan kening)

"Payudara nya kencang, terus gini lo (susunya diangkat), apa namanya loe diremes nanti ASI nya keluar sendiri, kalau saya seperti itu...."(partisipan 6)(partisipan terlihat memengang payudara)

Hasil triangulasi yang diperoleh peneliti melalui obsevasi adalah bahwa payudara partisipan kelihatan kencang dan membesar. Sesuai hasil observasi payudara partisipan dikatakan cukup ASI dengan katagori: kencang/tengang maupun membesar. Dan payudara partisipan dikatakan kurang ASI yaitu tanpa karakteristik payudara kencang/tegang maupun membesar. Pada observasi 24 jam pertama semua payudara partisipan 1-11 cukup dengan ASI. Untuk hasil observasi 72 jam pertama semua payudara partisipan 1-11 cukup dengan ASI.

6. Bagaimana keadaan payudara ibu sebelum menyusui? Apakah pernah ASI ibu keluar tanpa disusui? Bisa ibu jelaskan?

Delapan partisipan (70\%) dalam wawancara mengatakan bahwa sebelum disusukan payudara patisipan terasa kencang/tegang seperti kutipan di bawah ini :

"Ya sekarang kencang mb....sampek netes bajunya basah hehehee" (partisipan 1,7,9,11) (partisipan terlihat tertawa menunjuk payudara)

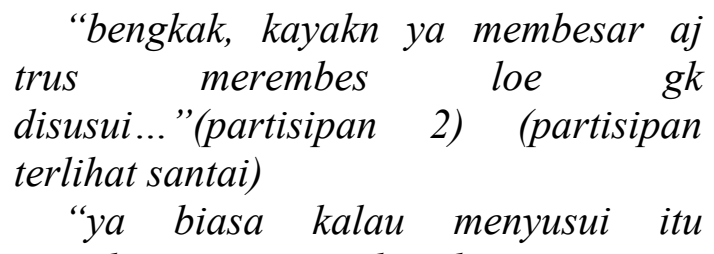
payudaranya emang kayak gini ... ya itu kencang hehehe (tertawa)...."ASI nya keluar sendiri loe lgi penuh (partisipan 3) (partisipan terlihat serius)

"Ya terasa ASInya penuh aja trus keluar sendiri nanti ....”.(partisipan 4) (partisipan terlihat serius)

"Payudara nya kencang, terus gini lo (susunya diangkat), apa namanya loe diremes nanti ASI nya keluar sendiri, kalau saya seperti itu...."(partisipan 6) (partisipan terlihat menunjuk payudara)

Hasil triangulasi yang diperoleh peneliti melalui obsevasi adalah bahwa payudara partisipan kelihatan kencang dan membesar. Sesuai hasil observasi payudara partisipan dikatakan cukup ASI dengan katagori: kencang/tengang maupun membesar. Dan payudara partisipan dikatakan kurang ASI yaitu tanpa karakteristik payudara kencang/tegang maupun membesar. Pada observasi 24 jam pertama semua payudara partisipan 1-11 cukup dengan ASI. Untuk hasil observasi 72 jam pertama semua payudara partisipan 1-11 cukup dengan ASI.

7. Apakah bayi ibu baru lahir dapat menyusu sendiri?

Sembilan partisipan $(70 \%)$ dalam wawancara mengatakan bahwa bayinya mampu menyusu sendiri setelah lahir seperti kutipan di bawah ini :

Bisa mb. waktu bis lahiran bayinya ditaruh di perut trus dia netek sendiri langsung bisa ngenyot dia.... (partisipan 1,2,7,9,11) (partisipan terlihat serius)

Yaa mampu dia menyusu, setelah lahir dedeknya disuruh nyusu langsung bisa ngenyot sendiri dia, mungkin alami kayak gitu yaa...( partisipan 3) (partisipan terlihat malu-malu) 
Habis lahiran nangis kenceng banget trus saya dikasi,, ya nyusu sendiri dedeknya... (partisipan 4) (partisipan terlihat berseri-seri)

Yaaaa bisa dia nyusu sendiri, mencari tetek dedeknya sendiri... (partisipan 6,8) (partisipan terlihat senyum -senyum)

Hasil triangulasi yang diperoleh peneliti melalui obsevasi adalah bahwa bayi partisipan kelihatan mampu menyusui sendiri. Sesuai hasil observasi bayi partisipan dikatakan mampu menyusui dimana bayi dapat menemukan putting susu ibunya sendiri. Pada observasi 24 jam pertama semua bayi partisipan mampu menyusu sendiri. Untuk hasil observasi 72 jam pertama semua bayi partisipan mampu menyusui dengan benar.

8. Bagaimana isapan bayi ibu saat menyusu?

Semua partisipan mengataka bahwa isapan bayinya kuat dengan ditandai mampu menyusu dengan benar, seperti kutipan dibawah ini:

Bisa mb... kuat banget ampek bunyi kadang-kadang .....(partisipan 2,4,5,7) (partisipan memperangakan gaya bayinya menyusu)

Isapan nya kuat sekali kayak kelaparan banget, sambil merem melek dia ngenyot heee ( partisipan 1,6) (partisipan terlihat malu-malu)

Ya bisa, kuat mb heee (partisipan 3, 8 , 10) (partisipan terlihat menggerutkan kening)

Duuh kuat banget nyusunya, bangun nagis netek lagi gitu aja .... (partisipan 9,11) (partisipan terlihat kelelahan)

Hasil triangulasi yang diperoleh peneliti melalui obsevasi adalah bahwa bayi partisipan isapannya kuat. Sesuai hasil observasi bayi partisipan mampu menyusu dengan benar dan tidak membutuhkan makanan pendamping selain ASI, serta ASI partisipan mampu memenuhi kebutuhan bayi partisipan.
Pada observasi 24 jam pertama semua bayi partisipan mampu menyusu sendiri dengan isapan yang kuat. Untuk hasil observasi 72 jam pertama semua bayi partisipan mampu menyusui dengan benar.

9. Menurut ibu berapa kali sehari bayi sebaiknya diberi ASI? Bagaimana pola tidur bayi ibu setelah menyusu?

Sepuluh partisipan $90 \%$ di Rumah Sakit TK II Udayana Denpasar dalam wawancara mengatakan bahwa bayinya sering menyusui dalam sehari seperti kutipan dibawah ini:

"Nyusunya?? kayaknya sejam sekali nyusu mb...kira 15 ada lamanya, habis tidur dia, ya tenang baget tidurnya"(partisipan 1,6,7,8) (partisipan terlihat serius)

"Aduh berapa kali ya banyak banget $m b$, kuat banget nyusunya nyusu ampe tertidur pulas mb..."(partisipan 2) (partisipan terliaht menggerutkan kening)

"Eeee ya kalau lapar ya dia nyusu,,,lamanya lo dah kenyang berhenti dia, kerjaannya tidur mulu, kenyang tidur gtu aja dia"(partisipan 3) (partisipan terlihat tanpa ekpresi)

"Eee banyak eee...yaaa ada 8-10 kali ya ada 15 menitan atau lebih lah bu"(partisipan 4 )(partisipan sambil tertawa)

"Ya 10 kali lah....2 jam sekali nyusu 2 jam sekali nyusu..."(partisipan 5,9) (partisipan terlihat tegang)

"sering.... kalau bangun dikasi ASI ... (partisipan 10,11) (partisipan terlihat serius)

Hasil triangulasi yang didapatkan oleh peneliti melalui observasi adalah peneliti melihat bayi sering menyusu rata-rata 10-12 kali dalam sehari yang merupakan tanda kebutuhan bayi akan ASI cukup. Apabila frekuensi menyusu kurang dari 10-12 kali makan kebutuhan bayi akan ASI dikatagorikan kurang. Sesuai hasil pengamatan dalam 24 jam 
pertama yaitu semua bayi partisipan frekuensi menyusu adalah cukup. Dan untuk pengamatan 72 jam pertama yaitu semua bayi partisipan frekuensi bayi menyusu adalah cukup yaitu 10-12 kali dalam 24 jam.

Semua partisipan dalam wawancara mengatakan bahwa payudara partisipan penuh dengan tandatanda kecukupan ASI. Sepuluh partisipan $(90 \%)$ dalam wawancara mengatakan bahwa bayinya tidur dengan tenang, rata-rata lama tidur bayinya 2-3 jam setelah menyusu seperti kutipan dibawah ini :

"Ya lama ...ya kira-kira segitu (23jam),,kadang dia terbagun karena lapar, apalagi malamnya sering terbangun minta netek..(partisipan 1) (partisiapan terlihat tenang)

"Ya lumayan lama, kadang adiknya nyusu sambil tidur eeee"(partisipan 2) (partisipan terliahat malu-malu)

"tidur -tidur aja soalnya memang umur segini yaaaa... tidur, lapar bangun, pipis bangun...gitu aja...."(partisipan 3) (partisipan terlihat menggaruk -garuk kepala)

"Ya lama .... ya 2-3 jam ada....."(partisipan 4,5,6,9) (partisipan terlihat serius)

"lama tidur kalau gak dibangunin gak bangun, ya lama ee 3-4 jam lah"(partisipan 7,8,10) (partisipan terlihat mengkerutkan kening)

"uuu tidur terus,,, ya tenang bangun nangis gitu ... kalau nangiskan tanda bagus....ya lama sie 4 jam ada"(partisipan 11) (partisipan terlihat serius)

Peneliti melihat semua bayi tidur rata-rata 3-4 jam. Jika bayi partisipan frekuensi tidurnya 3-4 jam maka bayi partisipan cukup dengan ASI. Dan apabila frekuensi tidurnya kurang dari 34 jam dalam 24 jam maka dikatakakan bahwa kebutuhan bayi partisipan akan ASI kurang.
10. Bagaimana reaksi wajah bayi ibu setelah menyusu? Berapa kali ibu menyusui bayi dalam sehari? Berapa lama biasanya bayi ibu menyusu? Berapa lama jeda ibu menyusui?

Delapan partisipan (90\%) di Rumah Sakit TK II Udayana Denpasar dalam wawancara mengatakan bahwa bayinya tidur tenang dan pulas setelah menyusu seperti kutipan dibawah ini :

"Ya tenang, nangisnya ya karena mau netek sama ngompol paling mb..."(partisipan 1) (partisipan terlihat mengkerutkan kening)

"Ya tenang tidurnya tenang tidurnya nyenyak pulas eeee..."(partisipan 2,3,4,5,7,8,9,10,11) (partisipan terlihat serius)

"Biasanya tenang, apa ya namanya mata nya itu merem melek, merem melek gitu apa yo (bingung) kedipkedip..."(partisipan 6) (partisipan terlihat mengkerutkan kening)

Hasil triangulasi yang didapatkan oleh peneliti melalui observasi adalah peneliti melihat semua bayi tidur dengan tenang setelah menyusu. Sesuai dengan hasil pengamatan 24 jam pertama bayi partisipan 1-11 bayinya tidur dengan tenang, dan hasil observasi 72 jam pertama bayi partisipan 1-11 bayinya tidur dengan tenang seperti pada gambar berikut.

11. Berapa kali bayi ibu kencing dalam sehari? Berapa kali mengganti popok dalam sehari? (popok kain) Berapa kali bayi ibu bab dalam sehari?

Semua partisipan di Rumah Sakit TK II Udayana Denpasar dalam wawancara mengatakan bahwa semua bayinya mengunakan popok kain, dan sering menganti popok jika bayinya buang air kecil/besar seperti kutipan dibawah ini :

"Berapa ya banyak mb lebih dari 10 kali kayaknya,,, soalnya dikit-dikit pipis 
dikit-dikit pipis"'(partisipan 1,4,10) (partisipan menggaruk-garuk kepala)

"Eeee.....7-8 kali ada

lah....."(partisipan 2,6,7) (partisipan terlihat mengkerutkan kening)

"Sehari ya ...banyak kadang sejam sekali ganti popok..."(partisipan 3) (partisipan terlihat serius)

"Duh banyak ya lebih dari itu (7-8 kali),,, soalnya nyusu aja kerjaan nya.....hehehe.."(partisipan

(partisipan terliaht tertawa)

"Kadang 7 kali kadang ya banyak banget sich (ketawa), duh berapa ya soal sering menyusui jadi kencingnya itu banyak banget setengah jam pipis setengah jam pipis."(partisipan 8,9) (partisipan mengkerutkan kening sambil tertawa)

"ganti popok berapa ya... semalam ada 4 kali, dari pagi banyak berapa ya 5 apa ya.... eee segitu deeh kayaknya..."(partisipan11) (partisipan menggaruk-garuk kepala)

Hasil triangulasi yang didapatkan oleh peneliti melalui observasi adalah peneliti melihat semua bayi mengaanti popok 7-8 kali. Yang dikatakan bayi cukup akan ASI apabila bayi buang air kecil/besar 6 kali dalam 24 jam. Apabila bayi buang air kecil/besar kurang dari 6 kali dalam 24 jam maka kebutuhan bayi akan ASI kurang. Disini peneliti melakukan observasi untuk melihat frekuensi buang air kecil/besar yaitu melalui jumlah mengganti popok. Sesuai hasil pengamatan 24 jam pertama semua bayi partisipan cukup ASI yang ditandai mengganti popok sebanyak 8 kali. Dan hasil pengamatan dalam 72 jam pertama semua bayi partisipan cukup ASI

\section{PEMBAHASAN}

\section{Interpretasi dan Diskusi Hasil}

1. Keadaan Payudara dan Tanda Kecukupan ASI bagi Bayi

Dari hasil penelitian yang dilakukan oleh peneliti diperoleh 11 partisipan, dalam wawancara menyatakan bahwa payudara partisipan terasa tegang atau kencang karena penuh dengan ASI. Meskipun pernyataan yang diungkapkan oleh partisipan berbeda-beda, namun maksud dan inti pernyataan partisipan sama yaitu mengatakan bahwa payudara partisipan terasa tegang atau kencang. Dimana penelitian yang dilakukan 24 jam pertama dan 72 jam pertama kemudian dilihat hasil akhirnya setelah melakukan proses Inisiasi Menyusui Dini. Seperti yang diungkapakan 10 partisipan (90\%), kutipan pernyataan partisipan "!...ya kencang, terasa kayak penuh..."

$$
\text { Satu partisipan }
$$

menyatakan bahwa payudaranya terasa biasa saja karena prepartisipan sudah memiliki pengalaman lebih tentang persalinan sehingga mengatakan payudaranya biasa saja dan wajar terasa tegang dan kencang sebelum menyusui. Kutipan pernyataan partisipan "ya biasa kalau menyusui itu payudaranya emang kayak gini ... ya itu kencang hehehe (tertawa).....". Dalam hal ini jumlah persalinan dan umur pasien tidak mempengaruhi produksi dan kelancaran ASI seperti yang dikatakan oleh Atikah\&Eni (2010) yaitu usia dan paritas tidak berhubungan dengan produksi ASI. Partisipan juga mengatakan bahwa mengalami tanda-tanda ASI nya penuh yaitu payudara partisipan membesar dan kencang, seperti kutipan pernyataan partisipan " $Y a$ kenceng, gede,,kalau lama gak nyusu kadang air susunya keluar hehehe ..." Demikian yang telah disampaikan oleh partisipan dalam wawancara, berdasarkan hasil observasi didapatkan data bahwa payudara partisipan Rumah Sakit Tk II Udayana Denpasar memiliki 
karakteristik yaitu kencang dan tegang serta dapat merembes keluar apabila dalam keadaan penuh tidak disusui. Seperti yang dikatakan oleh Bahiyatum (2008) kriteria yang dipakai sebagai patokan untuk mengetahui jumah ASI lancar atau tidak adalah ASI yang banyak dapat merembes keluar melalui putting, sebelum disusukan payudara terasa tegang/kencang. Dan semua hal-hal seperti diatas dialami oleh partisipan di Rumah Sakit Tk II Udayana Denpasar.

Menurut pendapat peneliti dengan karakteristik payudara partisipan tegang dan kencang yang ditandai ASI dapat merembes keluar sebelum menyusui hal ini merupakan tanda produksi ASI banyak. Yang dimana ASI akan memenuhi kelenjarkelenjar yang berada dalam payudara, sehingga dilihat dengan kasat mata payudara menjadi membesar, mengkilat, dan bahkan dapat keluar dengan sendirinya tanpa diisap oleh bayi partisipan. Seperti halnya sebuah balon yang diisi dengan air yang banyak, maka akan memiliki karakteristik yang hampir mirip dengan karakteristik payudara yang penuh dengan ASI. Hal tersebut jika ditambah dengan stimulus isapan bayi maka ASI dapat keluar secara lancar sehingga dapat memenuhi kebutuhan bayi akan ASI. Sehingga ibu-ibu tidak perlu memberikan susu formula sebagai makanan pendamping ASI, karena ASInya sudah memenuhi kebutuhan bayinya.

2. Kelancaran ASI pada Ibu Nifas di Rumah Sakit Tk II Udayana Denpasar

Dari hasil penelitian yang dilakukan oleh peneliti diperoleh 11 partisipan diwawancara menyatakan bahwa bayinya menyusui 1-2 jam sekali dalam sehari seperti kutipan pernyataan

partisipan "sering...mungkin 8 kali ada bahkan lebih...", "sehari 2 jam sekali nyusu...", "setiap sejam sekali,,,," dengan lama menyusui 15 menit seperti kutipan pernyataa partisipan "oooo.... Nyusunya tadi gak lama sie..ada 15 menitan",Eee... berapa ya lamanya eee segitu ada (15 menit)..hehehe (tertawa), "ya gak lama yaa...segitu ada (15 menit) dan bayi mengganti popok karena buang air kecil maupun besar dalam sehari 8-10 kali seperti kutipan pernyataan partisipan "kadang 7 kali kadang....ya banyak banget sieh..."(tertawa), "ganti popok berapa ya... semalam ada 4 kali, dari pagi banyak berapa ya 5 apa ya.... eee segitu deeh kayaknya..." serta bayi partisipan belum diberi makanan pendamping karena ASI partisipan masih dapat memenuhi kebutuhan bayi akan nutrisi.

Dari hasil observasi yang dilakukan peneliti, bayi tampak tenang saat tidur 3-4 jam /hari dengan tenang/pulas dan tidak rewel, menganti popok rata-rata 8-10 kali/hari, menyusui rata-rata 10-12 kali/hari dengan lama menyusui ratarata 15 menit. Seperti yang dinyatakan oleh Bahiyatum (2008) untuk mengetahui banyaknya produksi ASI, beberapa kriteria yang dipakai sebagai patokan untuk mengetahui jumah ASI lancar atau tidak ; ASI yang banyak dapat merembes keluar melalui putting, sebelum disusukan payudara terasa tegang, berat badan bayi naik dengan memuaskan sesuai umur, jika ASI cukup, setelah menyusu bayi akan tertidur /tenang selama 3-4 jam, bayi kencing lebih sering, sekitar 8 kali sehari. Menyusui 10-12 kali dalam 24 jam.

Menurut peneliti dengan kriteria diatas tersebut dapat dikatakan bahwa 
ASI partisipan di Rumah Sakit Tk II Udayana Denpasar keluar dengan lancar. Dengan pengeluaran ASI yang lancar sehingga dapat memenuhi kebutuhan bayinya. Hal tersebut sangat penting untuk pemenuhan nutrisi bayi kedepannya dalam mendukung pertumbuhan dan perkembangan bayi, sehingga menjadi individu yang sehat dan pintar. Dan langkah awal dalam mendukung program pemerintah dalam pemberian ASI eklusif selama 6 bulam pertama. Sehingga akan menciptakan SDM yang berkualitas agar mereka dapat melajutkan perjuangan pembangunan nasional untuk menuju masyarakat sejahtera, adil, dan makmur.

Seperti yang dikatakan oleh Atika \& Eni (2010) pendukung produksi ASI sehingga pengeluarannya lancar diantaranya isapan putting dapat merangsang serabut otot halus di dalam dinding saluran susu agar membiarkan susu dapat mengalir secara lancar, perawatan payudara, berat lahir, umur kehamilan saat melahirkan, stress dan penyakit akut, konsumsi rokok dan alkhohol, kontrasepsi, nutrisi ibu serta hal yang dapat mempengaruhi keadaan ibu. Produksi ASI dapat meningkat atau menurun tergantung pada stimulasi pada kelenjar payudara terutama pada minggu pertama laktasi.

Suradi (2010) menyatakan bahwa ASI dihasilkan oleh kerja gabungan hormon dan reflek. Selama kehamilan, terjadi perubahan hormon untuk menyiapkan jaringan kelenjar untuk membuat ASI. Segera setelah persalinan, perubahan hormon membuat payudara mulai menghasilkan ASI. Bila bayi mulai menghisap, dua refleks memungkinkan ASI keluar pada saat dan jumlah yang tepat, yaitu refleks prolaktin dan refleks let down (Suradi, 2010. Serta Bahiyatum (2008) juga menyatakan pada hari pertama, bayi cukup di susukan selama 10-15 menit, untuk merangsang produksi ASI dan membiasakan puting susu diisap oleh bayi.

Dari hasil penelitian yang bertujuan untuk mengevaluasi efektifitas Inisiasi Menyusu Dini terhadap kelancaran ASI pada ibu nifas di Rumah Sakit Tk II Udayana Denpasar diperoleh karakteristik payudara partisipan tegang dan kencang serta ditandai dengan payudara partisipan yang membesar dan ASI merembes. Hal tersebut menunjukan bahwa payudara partisipan produksi ASInya banyak. Serta bayi partisipan tidur tenang/pulas 3-4 jam, mengganti popok karena buang air kecil/besar 8-10 kali/hari, menyusui 10-12 kali/hari dengan lama 15 menit ini menunjukkan bahwa pengeluaran ASI partisipan lancar. Proses Inisiasi Menyusu Dini (IMD) paling tidak satu jam pertama setelah bayi lahir. Hal ini akan menunjang proses lancarnya ASI di kemudian hari. Dr.Utami Roesli SpA MBA IBCLC pakar ASI dan Sentral Laktasi Indonesia (2010).

\section{KESIMPULAN}

Berdasarkan hasil penelitian yang saya lakukan dapat disimpulkan sebagai berikut:

1. Karakteristik payudara pasien sebelum menyusui terasa tegang/kencang serta membesar. Hal ini menunjukan bahwa produksi ASI partisipan banyak.

2. Kelancaran ASI partisipan ditandai ASI dapat merembes sendiri, bayi partisipan buang air kecil 8-10 kali/hari bab 1-3 kali/hari, frekuensi menyusu 10-12 kali/hari, bayi partisipan tidak rewel dan tidur 3-4 
jam/hari dengan tenang dan dapat keluar secara lancar sehingga memenuhi kebutuhan bayinya akan ASI.

\section{DAFTAR PUSTAKA}

Ambarwati, E. (2009). Asuhan Kebidanan Nifas. Yogyakarta: Mitra Cendikia

Atikah \& Eni. (2010). Kapita Selekta ASI \& Menyusui. Yogyakarta: Nuha Medika

Bahiyatun. (2009). Buku Ajar Kebidanan Nifas Normal. Jakarta: EGC

Depkes RI. (2008). Pedoman Pengenalan Tanda Bahaya Pada Kehamilan, Persalinan dan Nifas Beberapa Keadaan Kehamilan yang Perlu Diwaspadai. Yogyakarta: Direktorat Bina Kesehatan Ibu

Sugiyono. (2016). Metode Penelitian Kuantitatif, kualitatif dan R\&D. Bandung: Alfabeta

Sulilawati. (2010). Pengeruh IMD terhadap Kelangsungan Pemberian ASI Ekslusif di Kabupaten Kamper Riau. Yogyakarta: Universitas Gajah Mada

Sulistyawati, A. (2009). Buku Ajar Asuhan Kebidanan pada Ibu Nifas. Yogyakarta: Andi

Suradi R, Tobing HKR (Ed), 2010. Manajemen Laktasi Cetakan Ke-2. Jakarta: BMD

Utami, R. (2008). Inisiasi Menyusu Dini dan Asi Eksklusif. Yogyakarta: Pustaka Bunda. 
Ni Wayan Purwaningsih: Evaluasi Efektifitas Inisiasi Menyusu Dini (IMD) terhadap Kelancaran ASI pada Ibu Nifas di Ruang Dahlia Rumah Sakit Tk II Udayana Denpasar 